\title{
THE IRREVOCABLE VIEW OF THE PHINEHASIAN COVENANT IN LIGHT OF THE DAVIDIC COVENANT*
}

\author{
Tuck Seon Chung $^{* *}$
}

\begin{abstract}
One may easily have the impression that the promise of an everlasting covenant with Phinehas in Numbers 25:13 has been reached under the Sinai covenant. On closer examination of the question, however, general agreement in fact counts for little. Rather, most of the questions on this point appear to be still open. This article re-examines the efficacy of the Phinehasian covenant by comparing parallelly with the Davidic covenant as to show that the covenant carries the same weight as the Davidic covenant. This paper emphasis on God's everlasting covenant with Phinehas is unconditional that should not be taken as a bilateral covenant under the Sinai covenant. Thus, how did Christ Jesus fulfill this Phinehasian covenant as the culmination of the covenant promise is worth for a further investigation.
\end{abstract}

Key words: Phinehasian covenant, Sinai covenant, Davidic covenant, Numbers

Abstrak: Orang mudah mendapatkan kesan bahwa janji kovenan kekal dengan Pinehas dalam Bilangan 25:13 telah digenapi dalam kerangka kovenan Sinai. Namun, melalui penyelidikan yang lebih mendalam, fakta-fakta yang mendukung ternyata sedikit. Sebaliknya, kebanyakan pertanyaan terhadap titik ini nampak masih terbuka. Artikel ini memeriksa kembali kekuatan kovenan Pinehas dengan cara membandingkannya parallel dengan kovenan Daud. Ia memandang bahwa kovenan kekal Allah dengan Daud adalah tidak

* This article is an excerpt of author's thesis “God's Everlasting Covenant With Phinehas" presented to the Southern Baptist Theological Seminary for Th. M degree in 2018.

** Penulis adalah dosen di Sabah Theological Seminary. 
bersyarat. Signifikansi dari riset ini adalah menguraikan bahwa kovenan Pinehas akhirnya terealisasi dalam Kristus Yesus sebagai kulminasi dari janji kovenan tersebut.

Kata-kata Kunci: kovenan Pinehas, kovenan Sinai, kovenan Daud, Bilangan.

\section{Introduction}

God's covenants with Israel feature prominently throughout the Old Testament. Therefore, biblical scholars over the last hundred years have examined the covenants extensively debating specifically their lasting significance. ${ }^{1}$ Most have concluded that the Mosaic covenant becomes obsolete with the arrival of the new covenant in Jesus Christ (Heb 8:13). Thus, scholars determine that the Levitical priesthood, for example, is irrelevant for contemporary New Testament studies due to its bilateral nature. ${ }^{2}$ In like manner, they disregard the Phinehasian

1. The origin and significance of the Old Testament covenant traditions became a subject of interest after the publication of Julius Wellhausen's Prolegomena to the History of Israel in 1885 (English translation)-see Ernest W. Nicholson, God and His People: Covenant and Theology in the Old Testament (New York: Oxford University Press, 1986), 3. See further discussion below. NB: The phrase ברית עולם is rarely given any significant treatment in typical covenant studies. In contrast, Steven D. Mason shows that ברית עולם "deserves special consideration because it is an important component of covenant theology in the Old Testament" [emphasis in the original]. Steven D. Mason, "Eternal Covenant" in the Pentateuch: The Contours of an Elusive Phrase, Library of Hebrew Bible/Old Testament Studies 494 (New York: T\&T Clark, 2008), 5-6.

2. Dongshin Don Chang points out that scholars ignore almost entirely the Levitical priesthood and covenant. This might be due to Wellhausen's negative view on the priestly sources $(P)$ and his appraisal of prophetic institutions seems to have persisted with the later scholars. See 
covenant (Num. 25:12-13) as having any eternal consequence. Instead, most scholars maintain that only the Noahic, Abrahamic, and Davidic covenants remain in effect given their unilateral terms. ${ }^{3}$ As a result, only certain covenants have garnered scholarly attention.

Upon initial examination, it may appear that a consensus has been reached regarding the main meaning of "forever" in the Phinehasian covenant. This is because the covenant was given as an extension under the Mosaic covenant, and is now considered obsolete. Upon closer study, the type of covenant and the specific term used with Phinehas are more closely associated with the Davidic covenant. In fact, most of the questions on this point still remain when comparing the Phinehasian covenant with the Davidic covenant. ${ }^{4}$

\section{The Promise of Everlasting Covenant with Phinehas}

The Phinehasian covenant has been substantially neglected and has become simplified as conditional under the Mosaic covenant.

Dongshin Don Chang, Phinehas, The Sons of Zadok, and Melchizedek: Priestly Covenant in Late Second Temple Texts (New York: Bloomsbury T\&T Clark, 2016), 4-7.

3. Major scholarship suggests that the Phinehasian covenant is obsoleted because this covenant was understood as an extension of the Mosaic covenant. For instance, Nichols, Walton, Matthews and Chavalas. Details see Greg Nichols, Covenant Theology: A Reformed and Baptistic Perspective on God's Covenants (Vestavia Hills: Solid Ground Christian Books, 2011), 120, 219-22. John H. Walton, Victor H. Matthews, and Mark W. Chavalas, The IVP Bible Background Commentary: Old Testament (Downers Grove: InterVarsity Press, 2000), 163.

4. This paper refers to the "Phinehasian priesthood" to encapsulate the Levitical priesthood and the Aaronic priesthood on the basis of the Phinehasian covenant. 
The obsolete view of the Phinehasian covenant will create more problems than it suggests. First of all, the nonfulfillment of the Phinehasian covenant will lead to the road of doubting God's faithfulness if the Phinehasian covenant is considered obsolete together with the Mosaic covenant. The fact that God had made the covenant with Phinehas is everlasting because unlike the Mosaic covenant, the promise with Phinehas does not depend on human obedience, but on God's character and God's sovereignty.

Secondly, there is no text in the Bible that associates both the Mosaic covenant and the Phinehasian covenant under the same entity. The Bible reveals that God instituted a lasting priesthood when he granted the covenant of peace with Phinehas. Numbers 25:13 describes this covenant as ברית כהנת עולם, a covenant of everlasting priesthood. This language raises the question as to the exact sense of perpetuity in the passage that brings resolution to the issue. There is tension if these two covenants are considered as one entity because the Phinehasian covenant is repeatedly and explicitly designated as "eternal" in the Old Testament, ${ }^{5}$ while the Mosaic covenant is not. So far, no solid proposal has been offered to explain whether the covenant with Phinehas is unconditional or the granted covenant is conditional as the Mosaic covenant that has the same characteristic of requiring human obedience to maintain the covenant.

5. For example, 1 Samuel 2:35, Malachi 2:4, 8; Psalms 106:31 and Nehemiah 13:29. 
The purpose of this paper is to provide another perspective on the Phinehasian covenant. It will reaffirm the validity of God's covenant with Phinehas by observing similar terms were used in the Davidic covenant. ${ }^{6}$ I propose that the Phinehasian covenant should not be considered as obsolete under the Mosaic covenant, but instead should be studied independently. ${ }^{7}$ Just as the Davidic covenant is separated from the Mosaic covenant, likewise the Phinehasian covenant should be separated from the Mosaic covenant.

\section{An Equivalent Comparison of the Covenants}

Wrong perceptions on the Phinehasian covenant may lead to false understanding of the Bible if the covenant is considered obsolete. For instance, following the obsolete view of the Phinehasian covenant would inevitably leads to despise the validity and significance of the law because the Mosaic law has to be obsolete when the Mosaic covenant

6. Similar positions are expressed by Thomas B. Dozeman, Richard Mayhue, Thomas Ice, and Scott W. Hahn. They stated that this promise is identical to the Davidic covenant which is both unconditional and everlasting. See Thomas B. Dozeman, "Numbers," in NIB (Nashville: Abingdon Press, 1998), 2:200; Richard Mayhue and Thomas Ice, "Covenants," in The Popular Encyclopedia of Bible Prophecy, ed. Tim LaHaye and Ed Hindson (Eugene: Harvest House, 2004), 61; Scott W. Hahn, Kinship by Covenant: A Canonical Approach to the Fulfillment of God's Saving Promises, The Anchor Yale Bible Reference Library (London: Yale University Press, 2009), 158-60.

7. The Phinehasian covenant should be remains relevant and treated as valid as the Davidic covenant. The scriptural evidence of both covenants is different and yet placed in parallel see Jeremiah 33:17-22; Ezekiel 37:26; and Zechariah 6:13. 
was broken. ${ }^{8}$ If caution is not taken, one might repeat the mistake of the Marcionites who rejected the authority of the Old Testament. ${ }^{9}$ Another major defect of the obsolete view is its teaching that the national people of "Israel" had been dismissed whereby the Abrahamic covenant which promise land to Israel has been terminated. The church alone will inherit the promise since the church is now identified as the "new Israel." ${ }^{10}$ The replacement analogy may lead to the conclusion that the church replaced Israel, or baptism has replaced circumcision. The great nuance about Israel and the church is that "the Gentile did not incorporate into

8. Thielman thinks that not only the portion of the law which regulates the priesthood and the sacrifices, but the entire law has been made obsolete. Frank Thielman, The Law and The New Testament: The Question of Continuity (New York: The Crossroad, 1999), 130-31.

9. Strawn's survey describes the concern that the use of the Old Testament is limited to choice verses and popular passages. Most people do not regard the Old Testament in the same way (or as highly) as the New Testament. Brent A. Strawn, The Old Testament is Dying: A Diagnosis and Recommended Treatment (Grand Rapids: Baker Academic, 2017), 5.

10. Romans 2:28-29; 9:6; Galatians 6:16; 1 Peter 2:9-10. The discussion regarding whether the church has replaced the nation of Israel is based on the understanding that Israel had failed just like Adam. Since Jesus is identified as the new Adam, the church is also identified with Jesus as the true Israel. The church is seen not merely as similar to Israel, but actually as Israel. G. K. Beale, A New Testament Biblical Theology: The Unfolding of the Old Testament in the New (Grand Rapids: Baker Academic, 2011), 653.

Supersessionism argues that the church permanently supersedes national Israel as God's people since the national Israel has been permanently rejected (Matt. 21:43). In interpreting the future of Israel, the supersessionists believe "all Israel" in Romans 11:26 refers to all the elect, including believing Jews and Gentiles. Some supersessionists also hold that Paul is speaking of a future large-scale conversion of Jews into the Christian church. Michael J. Vlach, Has the Church Replaced Israel? (Nashville: B\&H, 2010), 123, 137, 139. 
Israel, but a new sharing in Israel's prior covenants and promise."11 Even Paul did not use these two terms interchangeably in Ephesians 2:14. ${ }^{12}$ Thus, one must not ignore the specific role of Israel, or this mystery (Rom. 11:25) may not be conceived since the kingdom of God was taken from the current unbelieving Israel and given to the future believing Israel. ${ }^{13}$

As a matter of fact, the Phinehasian covenant should be considered as irrevocable based on the similar covenantal terms used in reference to the Davidic covenant. ${ }^{14}$ In contrast the distinctive difference between the Mosaic covenant and the Phinehasian covenant is that the Mosaic covenant is general and includes everyone in the community, but the Phinehasian covenant is one specific person being elected for the whole community. Same criteria of comparison should apply since one specific person being elected in the Davidic covenant is

11. Carl B. Hoch, Jr., "The New Man of Ephesians 2," in Dispensationalism, Israel and the Church: The Search for Definition, ed. Craig A. Blaising and Darrell L. Bock (Grand Rapids: Zondervan, 1992), 108.

12. Paul could have said that believing Gentiles were now part of Israel, but he did not. He carefully avoids the title "Israel." Vlach, Has the Church Replaced Israel? 152.

13. As Fruchtenbaum observes, "The point is that the kingdom, while taken from the present Jewish generation, will be given to a future generation of Israel." A. G. Fruchtenbaum, Israelology: The Missing Link in Systematic Theology (Tustin, CA: Ariel Ministries, 1989), 405. This is also the view of A. J. McClain, The Greatness of the Kingdom: An Inductive Study of the Kingdom of God (Winona Lake: BMH, 1959), 296-97, and Vlach, Has the Church Replaced Israel?, 142.

14. The nature of Phinehas's promise can be justified by comparing the identical covenantal phrase that is used in the Davidic covenant. Irvin A. Busenitz, "Introduction to the Biblical Covenants: The Noahic Covenant and the Priestly Covenant," The Master's Seminary Journal, 10/2 (1999): 186-89. 
considered as unilateral and therefore the unilaterality of the Phinehasian covenant should be considered in the same manner.

An equivalent comparison between the Phinehasian covenant and the Davidic covenant shows that a specific covenantal phrase was used in the Phinehasian covenant which also appeared in the Davidic covenant. The pattern laid down in Numbers 25:12-13 and Numbers 18:19 compare with Ezek 37:25-26 and 2 Chronicles 13:5 suggests that the similar covenantal language supports the idea that the Phinehasian covenant was expressed as a unilateral decree. Several lasting principles can be drawn from this comparison considering both covenants were rewarded as covenants of grant in recognition of meritorious conduct with similar covenantal phrase. This would suggest some equivalents of standard, namely the unilaterality and perpetuity, as the covenantal terms apply. ${ }^{15}$

\section{The Covenant of Peace}

First, special attention should be given to the establishment of this "covenant of peace," ברית שלום. According to Timothy Ashley,

15. Besides Abraham and David, Kline also sees Phinehas as the recipient of such covenants of grant as rewards for faithfulness. Meredith G. Kline, Kingdom Prologue: Genesis Foundations for a Covenantal Worldview (Overland Park: Two Age Press, 2000), 237.

16. The "covenant of peace" only appears four times in the Scripture (Num 25:12; Isa 54:10; Ezek 34:25, 37:26). The Hebrew construction for the phrase "my covenant of peace" (בריתי שלום) in Numbers is unusual because we do not usually find intervening pronominal suffixes in bound constructions. Allen, Numbers, 346. Anyhow, the Targum Neofiti 1 and the Targum Pseudo-Johathan retains the term as "covenant of 
God's promise to Phinehas is "my covenant of peace," where the covenant belongs to God and the word "covenant" here has the meaning of a "bond" of obligation. ${ }^{17}$ This bond of obligation is "as absolute and dependable as God" rather than "mutuality between parties." ${ }^{18}$ The consistency of the term in describing this covenant can be compared to the usage of this term in Ezekiel 37:25-26 as table 1 below.

\begin{tabular}{|c|c|}
\hline The "Covenant of Peace" in Numbers $25: 12-13$ & The "Covenant of Peace" in Ezekiel 37:25-26 \\
\hline $\begin{array}{l}\text { Therefore say, } \\
\text { 'Behold, I give him My covenant of peace } \\
\text { (בריתי שלום); and it shall be for him and his } \\
\text { descendants after him, a covenant of everlasting } \\
\text { priesthood (ברית כהנת עולם), because he was } \\
\text { jealous for his God and made atonement for the } \\
\text { sons of Israel. }\end{array}$ & 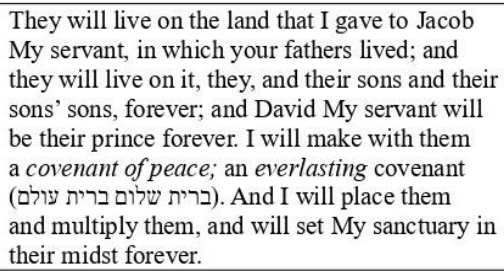 \\
\hline
\end{tabular}

Table 1. The equivalent comparison of the "covenant of peace"

Like the promises of restoration in Ezekiel 37, God will restore the nation of Israel like the resurrection of dry bones (v. 12) to become a people united (v. 22) under the new David (v. 24). This eschatological redemptive promise for the nation of Israel is "cut" (כרת) into a "covenant of peace" that serves as an "everlasting covenant" (v. 26). As an expression first used in Genesis 9:16, the "everlasting covenant" was God's plan to restore the earth "to be fruitful and multiply," this promise

peace." Martin McNamara and Ernest G. Clarke, trans., Targum Neofiti 1: Numbers, Targum Pseudo-Jonathan: Numbers, The Aramaic Bible, vol. 4 (Collegeville, MN: The Liturgical Press, 1995), 144, 265.

17. Timothy R. Ashley, The Book of Numbers, The New International Commentary on the Old Testament (Grand Rapids: Wm. B. Eerdmans, 1993, 522.

18. Ashely, The Book of Numbers, 522. 
of "everlasting covenant" is used again here and is inextricably connected to the clause of "I will multiply them" (Ezek 37:26) with the same order given to Adam (Gen 1:22), Noah (Gen 9:1) and Jacob (Gen 35:11; Exod 32:13). The theme of restoration for Israel here includes in retrospect of the creation. This can be seen in Ezekiel 34:25 where a "covenant of peace" is made for the Israelite to live in harmony with wild animals and sleep in the forest safely. The Israelites are connected to the former promises that they are going to live in the land exactly as promised by God's "everlasting covenant."

Again "re-creation" is a recurrent point in Isaiah 54:10 where God affirms that his "covenant of peace" with the Israelites will never be broken. God's mercy remains the same for the new restoration of Israel just as when God had sworn to Noah that a flood will never cover the earth again for the new creation (v. 9). As described in Isaiah 54:10, God's faithful love and his "covenant of peace" will remain forever. Punishment, like in the time of Noah, will not happen again since Noah brought back about reconciliation with God. ${ }^{19}$ Without any doubt the assurance of salvation contained in v. 10 is the promise of something that is to continue, a new condition of things. The second part of the passage (54:11-17) is described as the salvation for the future. The promise is then continued in 55:3, where an everlasting covenant with David is reiterated, and both in 56:4, 7, worship and sacrifice will be reinstate in the new era of salvation so that the foreigners' burnt

19. Noah built the first "altar" (מְזְבֵַ) that is recorded in Scripture. Willem A. VanGemeren, NIDOTTE (Grand Rapids: Zondervan, 1997), 2:889. 
offerings and sacrifices will be accepted on the altar. The context of "covenant of peace" in Isa 54:10 and the mention of Davidic covenant, to the reinstallation of priestly services in the Temple have demonstrated that both are closely related in the restoration of salvation.

The reading of the "covenant of peace" given under the Phinehasian covenant (Num 25:12) should be read in line with the "everlasting covenant" that has to do with this "restoration." The "covenant of peace" described in Ezekiel 34:25 and 37:26 which is a reminder of God's promise to restore Israel, is once again a blessing among the nations. Notably, the blessings of the "covenant of peace" are showered upon the people without any reference to obedience (Ezek 34:26). ${ }^{20}$ The theme of restoration is inseparable from its purpose, which is to worship the Lord. The climactic summary of restoration is that the people will worship in the sanctuary forever, for "the Lord will be their God, and they shall be the Lord's people" (Ezek 37:27). When God's sanctuary is set among them forever, it will never again be interrupted by further destructions. ${ }^{21}$ The divine mercy that granted this covenant is unconditional and required no obligation to keep the

20. Margaret S. Odell, Smyth \& Helwys Bible Commentary: Ezekiel (Macon: Smyth \& Helwys, 2005), 429.

21. Horace D. Hummel gave details elaborating on the establishment of God's eternal sanctuary "in the midst" of people implying that the Christological tabernacle will shelter the people of God. Horace D. Hummel, Ezekiel 21-48, Concordia Commentary (St. Louis: Concordia, 2007), 1095-97. 
covenant. In other words, the details of this "covenant of peace" more closely resembles the restoration of futuristic worship. ${ }^{22}$

S. M. Baugh mentions that the "covenant of peace" is particularly interesting because the covenant extended to Phinehas is later interpreted in Psalm 106 as being "credited to him as righteousness." 23 The same terms were used with Abraham in Genesis 15:6 that later granted him an unconditional covenant that required nothing of Abraham (Gen 15:18). The organic connection between imputation of righteousness and covenant is later developed by Paul in Romans 5:12$21 .{ }^{24}$ As "one righteous act resulted in justification and life for all people," Christ's righteous act has granted him a new covenant. This new covenant was granted by God as unilateral and is fulfilled by Christ eternally.

In short, the collective emphasis of Israel's restoration is to show that the establishment of the "covenant of peace" is justified. The "covenant of peace" woven together with the "everlasting covenant" was God's faithful promise that his covenant will not be removed. Therefore, the "covenant of peace" extended to Phinehas is consistent with the context throughout the whole Bible which is unilateral and cannot be removed.

22. Jesus is the One in whom all the covenants of the Old Testament find their fulfillment. In him, we have peace with God; in him, we have peace with one another and all creation.

23. S. M. Baugh, "Covenant Theology Illustrated: Romans 5 on the Federal Headship of Adam and Christ," Modern Reformation, 9, no. 4 (July/August 2000): 22.

24. Baugh, "Covenant Theology Illustrated": 22. 


\section{The Covenant of Salt}

It is remarkable that the "covenant of salt" only appeared in both the Phinehasian covenant and the Davidic covenant. The term is spoken two times (Num. 18:19 and 2 Chr. 13:5) in the Scripture, where the same idea was used in describing God's covenant with both Phinehas and David. ${ }^{25}$ The context in the Phinehasian covenant is described as a covenant of salt forever, ברית מלח עולם for both Aaron and his sons. A similar pattern is found in 2 Chronicles 13:5 where the kingship of Israel is given to David and his sons forever by a "covenant of salt" (ברית מלח).

The Rabbis interpret the term "covenant of salt" as to instruct that salt should never be lacking from sacrifices. The Talmud Menahot 19B21B mentions that the salting of the offering is indispensable because there is a covenant declared in regard to salt: ${ }^{26}$

For it has been taught: "It is a covenant of salt forever (Num. 18:19),' signifies that there is a covenant declared in regard to salt. So R. Judah. R. Simeon says, "Here we find 'It is a covenant of salt forever,' and elsewhere, 'The covenant of an everlasting priesthood' (Num. 25:13). Just as it is not possible for offerings to

25. Interestingly, the first time this phrase is found is in Leviticus 2:13, but the order is interpreted as "salt of covenant" (מֶלֵח בְּרִ the covenant is with salt itself. Salt was used in the grain offerings as preserving element indicating the perpetuity of God's commitment to Israel. Thus, it symbolizes that the covenant between the Lord and Israel was to be a binding covenant. Clyde M. Woods and Justin M. Rogers, LeviticusNumbers, The College Press NIV Commentary (Joplin: College Press, 2006), 49.

26. Jacob Neusner, The Babylonian Talmud: A Translation and Commentary, vol. 19, Menahot (Peabody: Hendrickson, 2005), 117, 127. 
be without the priesthood, so it is not possible for offerings to be without salt."

Scripture therefore states [concerning the salt], "it is a covenant of salt forever" (Num. 18:19), and elsewhere [in regard to the Shewbread], "it is on behalf of the children of Israel, a covenant forever" (Lev. 24:8). ${ }^{27}$

One may suggest that salt was used in the offerings as a preserving or purifying agent; however, the reasoning is not convincing. The grain offering (Lev. 2:13; Num. 18:9) which had no blood does not require preservation or cleansing. Furthermore, the term "covenant of salt" was also used with David which has no relationship to the customs of priestly offerings. Thus, the meaning of "covenant of salt" is not about the context of offerings, but about the "share" that God promised to Aaron and his sons as an inheritance as seen in the context of Numbers 18. God said the same to David-that he and his sons will inherit the throne of Israel forever (2 Sam. 7:12-13).

Both R. J. Coggins and Raymond Dillard agree that the "covenant of salt" implies an "eternal and efficacious covenant," making the covenant made with Phinehas just as permanent as the Davidic

27. Worth noting, the showbread is an "everlasting covenant" (ברית עולם); according to Mason, this specific phrase that rarely appears in the Old Testament functions as a "sign of the sign" for the presentation of the everlasting covenant of the Sabbath introduced in Exodus 31:16. Steven D. Mason, "Eternal Covenant" in the Pentateuch: The Contours of an Elusive Phrase, Library of Hebrew Bible/Old Testament Studies 494 (New York: T\&T Clark, 2008), 165. 
covenant since the term was equally applicable to the Phinehas line. ${ }^{28}$ Similarly, C. F. Keil and F. Delitzsch term this covenant of salt as an "indissoluble covenant" because the Lord has given the offerings to the priests as an eternal claim. ${ }^{29}$ For this reason, Aaron and the whole priesthood have no inheritance among the Israelites. As it is expressed, God was their share and inheritance (Num. 18:20). In addition, Baugh sees it from the perspective of a promised "inheritance" with perpetual priesthood..$^{30}$ Thus, the "covenant of salt" signifies a concept of an everlasting and unbreakable covenant and together with its dues implying an indispensable priesthood. In this sense, the connotations of eternality associated with the claim of "covenant of salt" in the Phinehasian covenant is again proven by the same term being used in the Davidic covenant. ${ }^{31}$

28. R. J. Coggins, The First and Second Books of the Chronicles (Cambridge: Cambridge University Press, 1976), 195; Raymond Dillard, 2 Chronicles, Word Biblical Commentary, vol. 15 (Waco: Word, 1987), 107.

29. C. F. Keil and F. Delitzsch, Biblical Commentary on the Old Testament (Grand Rapids: Eerdmans, 1949), 3:118.

30. Stephen M. Baugh, "Covenant Theology Illustrated: Romans 5 on the Federal Headship of Adam and Christ," MR 9:4, 22.

31. Everett Gill suggests the meeting of Jesus with the apostles as "Jesus ... being salted (=making a salt covenant) with them, charged them

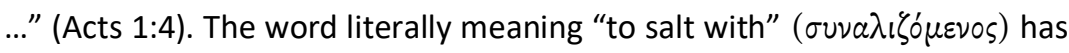
been translated either "to assemble" or "to eat with." Gill sees that the scholars have missed the beautiful connotation of this word because it is not ordinary "to come together" nor "to eat together." It should be a "covenantcoming-to-gather-and-eating." Everett Gill, "Jesus' Salt Covenant with the Eleven," Review \& Expositor 36/2 (1939): 197-98. For details of the issue, see discussion in bibliography in Don Garlington, "'The Salt of the Earth' in Covenantal Perspective," Journal of the Evangelical Theological Society 54/4 (2011): 744. 


\section{A Parallel Comparison with the Davidic Covenant}

With parallel comparison to the Davidic covenant, it is an idea of formal expression throughout the history of Israel in passing the understanding of the Phinehasian covenant. The most obvious evidence that the promise to Phinehas was an "everlasting covenant" can be found in Jeremiah. The words of the Lord came to Jeremiah twice and the oracles put both the Davidic covenant and the Phinehasian covenant in an equivalent comparison three times (see table 2).

\begin{tabular}{|c|c|c|}
\hline & Davidic covenant & Phinehasian covenant \\
\hline $\begin{array}{l}\text { First } \\
\text { comparison }\end{array}$ & $\begin{array}{l}\text { This is what the Lord } \\
\text { says: } \\
\text { v.17: David will never } \\
\text { fail to have a } \\
\text { man sit on the } \\
\text { throne of Israel, }\end{array}$ & $\begin{array}{l}\text { v.18: nor will the Levitical priests ever fail } \\
\text { to have a man to stand before } \\
\text { me continually to offer burnt } \\
\text { offerings, to burn grain offerings } \\
\text { and to present sacrifices. }\end{array}$ \\
\hline $\begin{array}{l}\text { Second } \\
\text { comparison }\end{array}$ & $\begin{array}{l}\text { This is what the Lord } \\
\text { says: } \\
\text { v.21: then my } \\
\frac{\text { covenant with }}{\text { David my }} \\
\text { servant }\end{array}$ & $\begin{array}{l}\text { and my covenant with the Levites who } \\
\text { are priests ministering before me- } \\
\text { can be broken and David will no } \\
\text { longer have a descendant to reign } \\
\text { on his throne. }\end{array}$ \\
\hline $\begin{array}{l}\text { Third } \\
\text { comparison }\end{array}$ & $\begin{array}{l}\text { v.22: I will make the } \\
\text { descendants of } \\
\text { David my servant }\end{array}$ & $\begin{array}{l}\text { and the Levites who minister before me } \\
\text { as countless as the stars in the sky } \\
\text { and as measureless as the sand on } \\
\text { the seashore. }\end{array}$ \\
\hline
\end{tabular}

Table 2. A parallel comparison of the two covenants in Jeremiah 33

God's statement is unequivocally assured to David's successor that the king's throne would be established forever, and at the same 
time the Phinehasian priesthood would be sustained forever as well. ${ }^{32}$ For instance, in the first comparison, Jeremiah 33:18 resembles an eschatological promise given to the descendants of Phinehas as well as a reiteration that the duties of the priests remain during the eschatological period. Similarly, the covenant with the Levites (Phinehas) was in parallel comparison with the Davidic covenant again in verse 21. In other words, both covenants carry the same weight which remain in force that cannot be broken "with the day and with the night" (Jer. 33:20). ${ }^{33}$ Moreover, in the third comparison, a similar emphasis about the Phinehas priesthood mentions that both the descendants of Phinehas and David will be as countless as the stars and the sand (Jer. 33:22), echoing the Abrahamic covenant (Gen. 22:17). This shows clearly that in the eye of God these two covenants are equivalent, side by side, and there is no hint that the Phinehasian covenant is viewed as a subordinate covenant to David.

32. Michael S. Kogan points out that Jeremiah included God's assurance that both the Davidic dynasty and the Phinehasian priesthood were to be eternal (Jer. 33:17-18). Kogan, Opening the Covenant, 63.

33. Charles Lee Feinberg makes an even stronger claim about the Phinehasian covenant being an everlasting covenant:

This passage has been a crux interpretum for expositors. It is especially difficult for those who hold an amillennial position in eschatology. The only resort for them is in allegorization of the text or the use of a dual hermeneutic. Simply stated, the passage assures that just as the Davidic covenant (2 Sam 7) is guaranteed by God's promise, so is the Levitical priesthood ... If the promises here are to be understood symbolically, this at once prejudges the disposition of the sacrifices in Ezek. 40-48, the interpretation of Isa. 66:21-23, and the treatment of Zech. 14:16-19. How are these passages to be handled? Charles Lee Feinberg, Jeremiah: A Commentary (Grand Rapids: Zondervan, 1982), 237. 
A similar emphasis about Phinehas's everlasting priesthood in God's long-term purposes is also found in Ezekiel. In Ezekiel 37:24-26, when God establishes David as a king forever, God's sanctuary will be set up "among them forever" too. The priests were implied in this text and are to serve God in the sanctuary forever (see table 2). They are not held accountable for their iniquity but continue to serve in the sanctuary (Ezek. 44:10-11). This shows the Phinehasian covenant is not broken. In fact, the "Levitical priests" will be fully restored (Ezek. 43:19; 44:15) once the great altar is restored. The Phinehasian priesthood is expected to continue to serve in the temple when God's glory returns to the eschatological temple.

\begin{tabular}{|l|l|}
\hline Davidic covenant & Phinehasian covenant implied \\
\hline $\begin{array}{l}\text { v.26: I will make a covenant of peace } \\
\text { with them; it will be an } \\
\text { everlasting covenant. I will } \\
\text { establish them and increase } \\
\text { their numbers, and }\end{array}$ & $\begin{array}{l}\text { I wem forever. } \\
\text { them fanctuary among }\end{array}$ \\
\hline
\end{tabular}

Table 2. The equivalent comparison of the two covenants in Ezekiel 37

\section{A Parallel Comparison with the Branch}

The idea of an everlasting priesthood of the Phinehasian covenant is shown when compared parallel with the crowning of the Branch in Zechariah 6:11-13. The oracle in Zechariah 6 focus on two figures-the Branch and the high priest. The coronation of the Branch with crowns is not explicitly stated. ${ }^{34}$ How many crowns are to be

34. Worth noting, the crowns are in plural form, עטרות. This would mean more than one crown (two?) is to be made and set it on the head of 
made and how many are to be placed on is not totally clear. ${ }^{35}$ Ambiguity arise where only one seat is available but the high priest Yeshua (יהושע), with a crown already on his head is to crown another man whose name is the Branch that will be seated on the same throne as the priest. As Barry Webb noted, the crowning of the high priest is unexpected since it was normally for kings and not priests. ${ }^{36}$

The mystery is solved if the role of the Branch and the role of the high priest are one person, where this throne of the king is also to be seated for the priest. ${ }^{37}$ It was mentioned that the high priest and kingship will become one and there will be harmony between the two (v. 13). ${ }^{38}$ The hinge point to solve this mystery lays on verse 13

the high priest and the Branch. James D. Nogalski, The Book of the Twelve: Micah-Malachi, SHBC (Macon: Smyth \& Helwys, 2011), 880.

35. Edgar W. Conrad suggests the scene maybe portraying two crowns were made from the two precious metals, one from silver and the other from gold since one of the crowns is placed on Joshua's head and the other on the Branch (Conrad, Zechariah [Sheffield: Sheffield Academic Press, 1999], 126).

36. Barry Webb, The Message of Zechariah, BST (England: InterVarsity Press, 2003), 107.

37. Childs suggests that the tradition of Zechariah and the subordination of the prince to the priests in Ezekiel 40-48 contribute to the two messiahs ideology for Qumran. Childs, Biblical Theology, 455.

38 Martin J. Selman suggests this passage together with other passages (i.e: Jer 33:14-26 and Ezek 37:24-28) that have royal and priestly anointed leaders are acting or ruling with righteousness and justice. In the matter of establishing the Davidic kingship, the spiritual values are important too. This achievement is not seen in military or political terms, but from the Levitical priesthood that brings belief into effect. Martin J. Selman, "Messianic Mysteries," in The Lord's Anointed: Interpretation of Old Testament Messianic Texts, ed. Philip E. Satterthwaite, Richard S. Hess, and Gordon J. Wenham (Grand Rapids: Baker Books, 1995), 291. 
where the natural sense of the Hebrew is to translate והיה as a thirdperson verb rather than as indicative. ${ }^{39}$ Alternative translations of והיה has been proposed and has been adopted in some English translations (see table 3). However, Webb argued it is unlikely since there is no indication a change of subject within the same verse.

\begin{tabular}{|c|c|}
\hline Zechariah 6:13 & \\
\hline שלום תהיה בין שניהם על־כסו ועצת & $\begin{array}{l}\text { ESV: And there shall be a priest on his } \\
\text { throne, and the counsel of peace shall be } \\
\text { between them both. } \\
\text { NRSV: There shall be a priest by his throne, } \\
\text { with peaceful understanding between the } \\
\text { two of them. } \\
\text { NIV: And He will be a priest on His throne, } \\
\text { and there will be harmony between the } \\
\text { two. } \\
\text { NASB: Thus, He will be a priest on His } \\
\text { throne, and the counsel of peace will be } \\
\text { between the two offices. } \\
\text { NKJV: So He shall be a priest on His throne, } \\
\text { And the counsel of peace shall be between } \\
\text { them both. }\end{array}$ \\
\hline
\end{tabular}

Table 3. Different version of translations for והיה.

Therefore, the priest is identical to the king since the Branch, $\mathrm{He}$ himself will be a priest on His throne. The sharing of the throne and the sharing of the power is nowhere more clearly evident than a priestlyking idea that lies in the future. This is an enigma that cannot be solved without the light of the New Testament where Jesus himself carries the priestly messiah and kingly messiah role at the same time. With Joshua

39. (Webb, The Message of Zechariah, 109n221). 
was already the high priest told in chapter 3 and in expecting of the Branch to come; being such, the union of the offices of high priest and king in the person of the Messiah should be first the high priest, then a kingly crown was added to him. In other words, the Phinehasian covenant is equally important as the promise about the coming of the Branch for it foreshadows the coming of the Messiah.

\section{Conclusion}

From what has been said so far, it becomes apparent that the Phinehasian covenant is as unilateral as God's promise to David since a similar phrase used in the Phinehasian covenant is also used in the Davidic covenant. Strikingly, the covenantal terms of "covenant of peace" and "covenant of salt" used in refer to the perpetuity of the Phinehasian covenant that should not be overlooked. In light of the Davidic covenant, the fact that the Phinehasian covenant remains, speaks even louder as a separate covenant when the Mosaic covenant was presented as obsolete. From the covenantal terminology used, it shows both covenants with Phinehas and David are equally important. The Phinehasian covenant never loses its luster even as it stands alongside the Davidic covenant.

Therefore, the Phinehasian covenant should be unilateral and should not be viewed as a subsidiary to the Mosaic covenant. Unlike the Mosaic covenant, there should be no terms towards the Phinehasian covenant because it is irrelevant to the commitment of the covenant. It is appropriate for the study of covenants today to recapture this 
Phinehasian covenant, especially in parallel comparison with the Davidic covenant. Most importantly, as Hahn concludes, it would be unwise to neglect this covenant, because the nonfulfillment of the Phinehasian covenant portrays the idea that God did not fulfill his covenant with Phinehas and that would be exegetically and theologically incorrect. ${ }^{40}$ Rather, it should be given a lofty place with the same treatment as the Davidic covenant and we should put the Phinehasian covenant back within the proper biblical context from which the covenant was uprooted.

\section{Reference}

Beale, G. K. A New Testament Biblical Theology: The Unfolding of the Old Testament in the New. Grand Rapids: Baker Academic, 2011.

Behm, Johannes. " $\delta 1 \alpha \theta \eta^{\prime} x \eta$," in TDNT. Grand Rapids: Eerdmans, 2006.

Baugh, Stephen M. "Covenant Theology Illustrated: Romans 5 on the Federal Headship of Adam and Christ." MR 9:4, 22.

Busenitz, Irvin A. "Introduction to the Biblical Covenants: The Noahic Covenant and the Priestly Covenant." The Master's Seminary Journal 10/2 (1999): 173-89.

Chang, Dongshin Don. Phinehas, The Sons of Zadok, and Melchizedek: Priestly Covenant in Late Second Temple Texts (New York: Bloomsbury T\&T Clark, 2016), 4-7.

Childs, Brevard S. Biblical Theology of the Old and New Testaments: Theological Reflection on the Christian Bible. Minneapolis: Fortress, 1992.

Coggins, R. J. The First and Second Books of the Chronicles. Cambridge: Cambridge University Press, 1976.

Conrad, Edgar W. Zechariah. Sheffield: Sheffield Academic Press, 1999.

Dillard, Raymond. 2 Chronicles. Word Biblical Commentary, vol. 15. Waco: Word, 1987.

40. Hahn, Kinship by Covenant, 174-75. 
Dozeman, Thomas B. "Numbers," in NIB. Nashville: Abingdon, 1998. Ellingworth, Paul. The Epistle to Hebrews: A Commentary on the Greek Text. Grand Rapids: Eerdmans, 1993.

Feinberg, Charles Lee. Jeremiah: A Commentary. Grand Rapids: Zondervan, 1982.

Esser, H. "Law," "vópos," in NIDNTT, 2:438-51.

Fruchtenbaum, A. G. Israelology: The Missing Link in Systematic Theology. Tustin, CA: Ariel Ministries, 1989.

Gill, Everett. "Jesus' Salt Covenant with the Eleven," Review \& Expositor 36/2 (1939): 197-98.

Garlington, Don. "The Salt of the Earth' in Covenantal Perspective." Journal of the Evangelical Theological Society 54/4 (2011): 71548.

Grudem, Wayne. Systematic Theology: An Introduction to Biblical Doctrine. Grand Rapids: Zondervan, 1994.

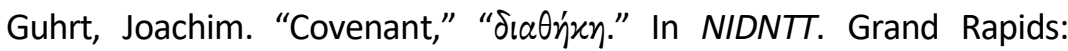
Zondervan, 1975.

Hahn, Scott W. Kinship by Covenant: A Canonical Approach to the Fulfillment of God's Saving Promises, The Anchor Yale Bible Reference Library. London: Yale University Press, 2009.

Hoch, Carl B., Jr. "The New Man of Ephesians 2." In Dispensationalism, Israel and the Church: The Search for Definition, edited by Craig A. Blaising and Darrell L. Bock. Grand Rapids: Zondervan, 1992.

Joslin, Barry C. Hebrews, Christ, and the Law: The Theology of the Mosaic Law in Hebrews 7:1-10:18. Eugene: Wipf and Stock, 2009.

Keil, C. F. and F. Delitzsch. Biblical Commentary on the Old Testament. Grand Rapids: Eerdmans, 1949.

Kline, Meredith G. Kingdom Prologue: Genesis Foundations for a Covenantal Worldview. Overland Park: Two Age Press, 2000.

Kogan, Michael S. Opening the Covenant: A Jewish Theology of Christianity. Oxford: Oxford University Press, 2008.

Mason, Steven D. "Eternal Covenant" in the Pentateuch: The Contours of an Elusive Phrase. Library of Hebrew Bible/Old Testament Studies 494. New York: T\&T Clark, 2008.

Mayhue, Richard and Thomas Ice, "Covenants." In The Popular Encyclopedia of Bible Prophecy, edited by Tim LaHaye and Ed Hindson. Eugene: Harvest House, 2004. 
McClain, J. The Greatness of the Kingdom: An Inductive Study of the Kingdom of God. Winona Lake: BMH, 1959.

McComiskey, Thomas Edward. The Covenants of Promise: A Theology of the Old Testament Covenants. Grand Rapids: Baker, 1985.

McConville, Gordon J. "בְּרִּרית." In NIDOTTE, edited by Willem A.

VanGemeren. Grand Rapids: Zondervan, 1997.

Neusner, Jacob. The Babylonian Talmud: A Translation and Commentary, vol. 19. Menahot. Peabody: Hendrickson Publishers, 2005.

Nichols, Greg. Covenant Theology: A Reformed and Baptistic Perspective on God's Covenants. Vestavia Hills: Solid Ground Christian, 2011.

Nicholson, Ernest W. God and His People: Covenant and Theology in the Old Testament. New York: Oxford University Press, 1986.

Nogalski, James D. The Book of the Twelve: Micah-Malachi. SHBC. Macon: Smyth \& Helwys, 2011.

Räisänen, Heikki. Paul and the Law. Philadelphia: Fortress Press, 1986.

Roper, David H. The New Covenant in the Old Testament. Waco: Word, 1976.

Rosner, Brian S. Paul and the Law: Keeping the Commandments of God. Downers Grove: InterVarsity Press, 2013.

Schreiner, Thomas R. "Paul's view of the Law in Romans 10:4-5," Westminster Theological Journal 55 (1993): 113-35.

Strawn, Brent A. The Old Testament is Dying: A Diagnosis and Recommended Treatment. Grand Rapids: Baker Academic, 2017.

hielman, Frank. The Law and The New Testament: The Question of Continuity. New York: The Crossroad, 1999.

Vlach, Michael J. Has the Church Replaced Israel? Nashville: B\&H, 2010. Walton, John H. Victor H. Matthews, and Mark W. Chavalas, The IVP Bible Background Commentary: Old Testament. Downers Grove: InterVarsity Press, 2000.

Webb, Barry. The Message of Zechariah. BST. England: InterVarsity Press, 2003.

Woods, Clyde M. and Justin M. Rogers. Leviticus-Numbers. The College Press NIV Commentary. Joplin: College Press, 2006.

Wright, N. T. The Climax of the Covenant: Christ and the Law in Pauline Theology. Minneapolis: Fortress, 1991. 